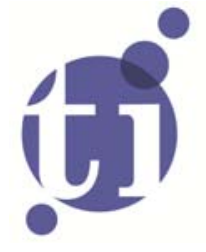

\title{
Are CEOs incentivized to avoid Corporate Taxes? - Empirical Evidence on Managerial Bonus Contracts
}

\author{
Heiner Schmittdiel
}


Tinbergen Institute is the graduate school and research institute in economics of Erasmus University Rotterdam, the University of Amsterdam and VU University Amsterdam.

More TI discussion papers can be downloaded at http://www.tinbergen.nl

Tinbergen Institute has two locations:

Tinbergen Institute Amsterdam

Gustav Mahlerplein 117

1082 MS Amsterdam

The Netherlands

Tel.: +31(0)205251600

Tinbergen Institute Rotterdam

Burg. Oudlaan 50

3062 PA Rotterdam

The Netherlands

Tel.: +31(0)10 4088900

Fax: $+31(0) 104089031$

Duisenberg school of finance is a collaboration of the Dutch financial sector and universities, with the ambition to support innovative research and offer top quality academic education in core areas of finance.

DSF research papers can be downloaded at: http://www.dsf.nl/

Duisenberg school of finance

Gustav Mahlerplein 117

1082 MS Amsterdam

The Netherlands

Tel.: +31(0)20 5258579 


\title{
Are CEOs Incentivized to Avoid Corporate Taxes? \\ - Empirical Evidence on Managerial Bonus Contracts
}

\author{
Heiner Schmittdiel*
}

March 25, 20I4

\begin{abstract}
In this paper, we test empirically whether there is a relationship between corporate income taxes and CEO bonus payments. Using Compustat and ExecuComp data from 1992 to 2010 , we find mixed results. Looking at the whole sample, the average bonus contract rewards tax savings excessively in comparison to other determinants of corporate net income. A possible explanation is that managers require to be compensated for the additional risk inherent in running an aggressive tax strategy. In accordance with previous literature, we document a substantial heterogeneity in compensation practices across industries. It appears that our main result is driven by firms in the $\mathrm{In}^{-}$ dustrial and Retail sectors. We further find that companies with greater tax planning opportunities, for example by virtue of size or operations abroad, are more likely to condition the CEO's bonus on corporate income taxes.
\end{abstract}

Keywords: CEO incentives, executive compensation, tax avoidance.

JEL: $\mathrm{H}_{25}, \mathrm{H}_{26}, \mathrm{M}_{41}, \mathrm{M}_{52}$.

\footnotetext{
${ }^{*}$ Tinbergen Institute and Department of Economics, Erasmus University Rotterdam. E-mail: schmittdiel@ese.eur.nl
} 


\section{Introduction}

One of the central questions in Corporate Governance is how to align the incentives of the Chief Executive Officer (CEO) with those of the owners of a firm. An apparent method to do so is tying the executive's compensation to corporate performance, for example by means of equity pay or a bonus based on accounting measures. Previous studies confirm that CEO pay is indeed related to firm performance and find total CEO wealth to increase by median values of 3.25 dollars (Jensen and Murphy I990) or 5.29 dollars (Hall and Liebman I998) following a I,O00 dollar increase in shareholder wealth. ${ }^{2}$ Not only do the level and the composition of executive compensation vary greatly across firms and industries (cf. Murphy 1999), but they also change quite remarkably over time (see Figure I).

Investors care about the return on their investment in a firm, that is, the sum of stock price changes and paid dividends, relative to the principal investment. Assuming the CEO disposes of means to reduce his company's tax obligations and that the expected gains of such conduct exceed the expected costs for the shareholders, it would be rational for the owners of a firm to set corresponding incentives for top management. Dyreng et al. (2008) note that "[a]voiding taxes does not imply anything improper. Indeed, firms (and individuals) can avoid Federal [sic] income taxes through means as simple as holding municipal bonds that generate tax-exempt interest income" (p. 65). Apart from making use of such tax exemptions, firms may reduce their tax burden by exploiting differences in local tax rates, by financing themselves with debt rather than equity, or simply by misreporting revenue or

\footnotetext{
${ }^{\mathrm{I}}$ Executive compensation packages can generally consist of a number of parts: a base salary, an annual bonus based on accounting measures, stock options, long-term incentive plans such as restricted stock plans, and other benefits such as perquisites, insurances, pensions, or severance pay.

${ }^{2}$ These studies focus on changes in executive wealth rather than just on income in order to take into account the effect of corporate performance on the CEO's equity holdings.
} 


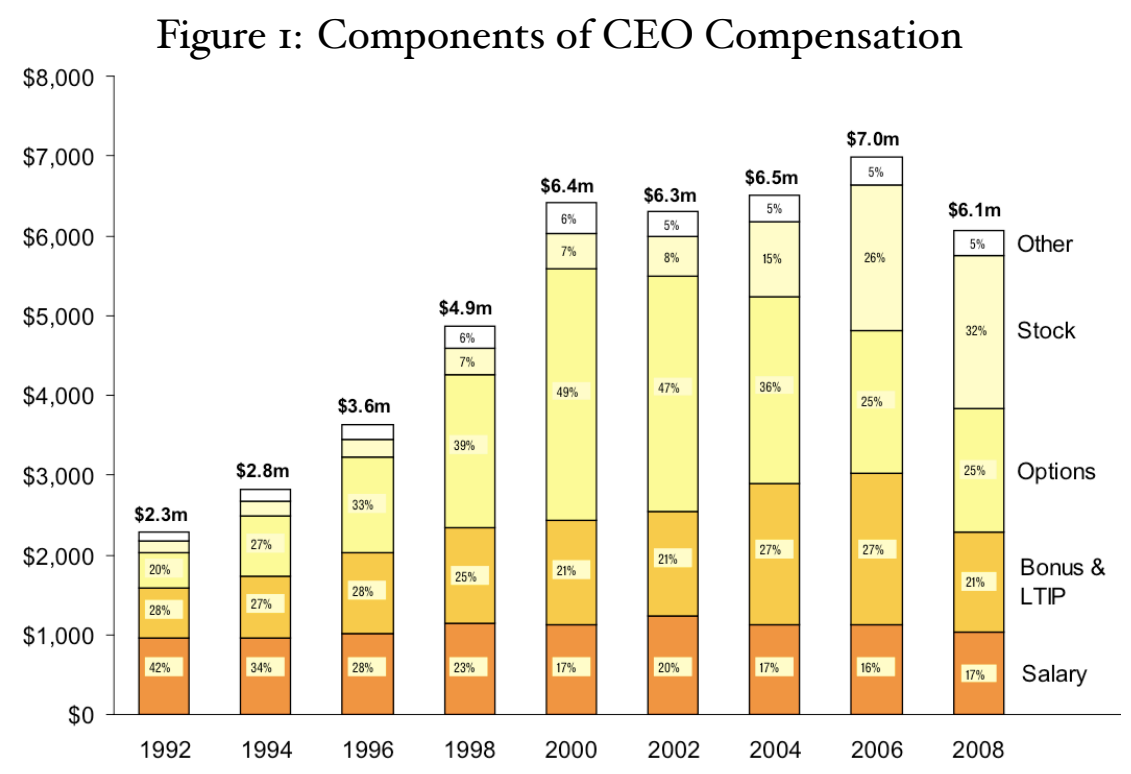

Level and structure of CEO Compensation in S\&P 500 firms, in thousands of year-2000 dollars (Source: Frydman and Jenter 20IO).

business expenses. ${ }^{3}$ If the $\mathrm{CEO}$ can avail himself of such a measure to reduce tax payments, an apparent question is how the shareholders can effectively encourage such behavior.

Firms can ensure that the CEO acts in the shareholders' interest by making him a shareholder himself (for example by paying him in firm equity and limiting his possibility to sell it). Nonetheless, according to Murphy (1999) almost all for-profit companies make use of bonuses in addition to or instead of equity incentives. Assuming the stock price correctly evinces the value of a firm, equity incentives implicitly motivate the CEO to reduce corporate tax payments, since this will lead to a higher net income of the company, and thus to a higher firm value. However, it is unclear whether bonus contracts set such incentives. This depends on what accounting measure a bonus is based on. The literature suggests that the most prevalent perfor

${ }^{3}$ Corporate tax rates do not only vary internationally, but also between U.S. states and municipalities. 
mance measure used in bonus contracts is firm profits. Murphy (2000) finds $91 \%$ of large firms to tie the CEO's bonus to either net or gross accounting profits. Ittner et al.'s (1997) text-search of proxy statements only finds $25.3 \%$ of firms to use pre-tax and $27.2 \%$ post-tax income as performance measures. It must be noted, however, that other measures can indirectly set incentives to increase profits and/or reduce taxes. $^{4}$

In this paper, we test empirically whether CEOs' bonus payments are related to corporate income taxes. We do so by running regressions of bonus payments on income taxes, controlling for firms' net profits. While public corporations are required to disclose the amount and composition of executive compensation, the exact remuneration contract is generally unobserved. Studies on managerial bonus contracts therefore rely on information that some firms communicate voluntarily, for example in their proxy statements. We add to the literature in two ways. First, we make use of panel data with a sample of firms that is much broader than that in other studies which are constrained by the number of firms for which enough information is available. This approach gives our study more external validity. Second, our approach of estimating the nature of bonus contracts, rather than conducting a survey or otherwise making use of information controlled by the firm, allows us to rule out concerns such as nonresponse bias, selection bias, and even firms or their consultants intentionally giving misleading information (cf. Slemrod 2007). The next section provides an overview of the related literature. Section 3 describes the data and the econometric framework. Results are presented and discussed in Section 4 , followed by a concluding section.

\footnotetext{
${ }^{4}$ According to Ittner et al. (1997) and Murphy (2000), other popular financial performance measures in bonus plans are earnings per share, return on equity, sales, cash flow, return on assets, and cost reduction.
} 


\section{Related Literature}

If corporate income taxes were determined in an inexorable fashion, there would be little justification for conducting our study. However, recent research suggests that companies have an array of possibilities to manipulate their income tax payments, both legally and illegally. This section summarizes three streams of literature, beginning with some theoretic implications of including tax considerations in a principalagent framework. The second group of studies aims at investigating whether firms pay less taxes when the CEO is incentivized accordingly, which further motivates our study. Finally, we derive some indications for our empirical analysis from two papers that examine what kind of firms engage in income tax evasion.

\section{Theory of Incentives to Avoid Taxes}

Allingham and Sandmo (1972) develop a model of individual tax evasion based on Becker's (I968) notion that a person will commit an unlawful act whenever the expected utility from doing so exceeds the expected disutility of punishment. In a corporate setting ownership and control are separated, making the problem more complex. Crocker and Slemrod (2005) use a costly state falsification framework in the formalization of the contract between shareholders and the executive, in which the executive can evade corporate taxes legally (costless) or illegally (costly to shareholders and executive).5 The degree to which he can evade taxes legally is a random variable and private information for him. The central finding of the model is that illegal tax evasion decreases with higher penalties to either shareholders or the $\mathrm{ex}^{-}$ ecutive, but that penalizing the executive is generally more effective. This is so

${ }^{5}$ Crocker and Slemrod (2005) base their arguments on the contract of the Chief Financial Officer (CFO). While the CFO may have a more direct say in a firm's tax issues, Phillips (2003) and Dyreng et al. (2OIO) support the view that focussing on the CEO can be justified with his predominant position in the company. 
because the information asymmetry concerning the possibilities of legal tax evasion necessitates a second-best compensation contract. Note that Crocker and Slemrod (2005) assume not only the shareholders but also the executive to be risk-neutral agents.

This last concern is addressed by Chen and Chu (2005) who model the executive to be risk-averse. Unlike Crocker and Slemrod (2005), they further assume that the firm owners can observe whether or not illegal tax evasion is carried out. When tax evasion is detected by the authorities, the CEO incurs a cost. ${ }^{6}$ However, firm owners cannot credibly condition the compensation contract on whether or not tax evasion is detected, because the contract would not hold up in court. ${ }^{7}$ As a consequence, the shareholders must reward the executive for tax evasion ex ante, regardless of whether or not it is detected and punished. While this signifies an efficiency loss compared to a scenario where detection is contractable, it may still be worthwhile for firm owners to incentivize tax evasion.

Desai and Dharmapala (2006) develop a model that incorporates the two following considerations: I) Incentive compensation aligns the executive's incentives with those of the shareholders, so that he tries to reduce tax payments whenever this increases firm value. 2) Tax sheltering and managerial rent extraction are complementary activities. Thus, it is unclear whether incentive compensation leads to an aggressive tax strategy or not.

\footnotetext{
${ }^{6}$ The paper also studies the case of a non-liable CEO, which we do not discuss for the sake of brevity.

${ }^{7}$ The relevance of this argument can be questioned, however. First of all, it does not play a role in legal tax evasion. Second, the CEO may enforce the payment of higher compensation when illegal evasion is detected, for example by threatening to disclose other information that is harmful to the shareholders.
} 


\section{Do such Incentives Work?}

One commonly used measure of the extent of tax avoidance is the book-tax gap: the difference between income reported to shareholders (as laid out in the United States Generally Accepted Accounting Principles) and that reported to tax author ities. Another, very similar, approach is to look at the effective tax rate (ETR) of a firm which is equal to the ratio of cash taxes to pretax income. In their empirical application with Compustat and ExecuComp data from the years 1993 to 2002, Desai and Dharmapala (2006) find that higher stock-based compensation is associated with a lower level of tax sheltering, as measured by the book-tax gap that does not stem from accounting accruals. They argue that this negative effect is driven by poorly-governed firms, for which the authors assume that there is a positive feedback between diversion of funds and tax sheltering, in other words: an increase in the manager's participation in firm value will lead him to divert less funds, which, in weakly-governed firms, is assumed to make tax sheltering more costly. ${ }^{8}$

Rego and Wilson (2OI2), on the contrary, state that for an executive to follow an aggressive tax strategy, high levels of equity risk incentives need to be put in place. They argue that if the CEO holds stock options of his firm, their value increases with stock return volatility so that he is incentivized to undertake risky activities with a positive net present value; one such risky activity may be an aggressive tax strategy. Using data from Compustat, ExecuComp, and CRSP for the years 1992 to 2006, Rego and Wilson (2OI2) find a positive relationship between several measures of tax aggressiveness, such as discretionary book-tax differences or the average ETR, and

\footnotetext{
${ }^{8}$ They offer a case study to illustrate the intuition of such a positive feedback mechanism between tax sheltering and diversion of funds, stating that "features of [a tax-oriented] transaction designed to make it more opaque to the capital markets were justified on the basis of secrecy, supposedly necessitated by tax objectives" and that "actions that served as the origins of the conspiracy to mislead the auditors were also justified on this same basis" (p. 157).
} 
the manager's equity risk incentives, which are modeled as the change in the value of stock options held by the CEO. Similar in spirit, Armstrong et al. (2OI2) make use of a proprietary data set from a human resource consultant for the years 2002 to 2006 and find a positive relation between several measures of tax avoidance and the compensation mix. They define this variable as the ratio of variable compensation to total compensation. ${ }^{9}$ While this can serve as an approximation of the intensity of the manager's general incentivation, it is unclear what part of it puts it in the executive's interest to reduce his firm's income tax payments.

In summary, the empirical evidence on whether equity risk incentives can induce corporate tax avoidance is unclear. Desai and Dharmapala's (2006) analysis can serve as one explanation why shareholders cannot always rely on equity incentives to encourage tax evasion. As a result, they may choose to resort to bonus contracts that incentivize management to run an aggressive tax strategy. Another explanation could be that shareholders choose a bonus plan to set these incentives because accounting measures are a less noisy signal of managerial actions than the stock price (cf. Murphy 1999).

Focussing on accounting-based compensation, Phillips (2003) investigates if aftertax incentives - that is, compensation that is based on an after-tax accounting measure - lead executives to conduct a more aggressive tax strategy. Using a combination of Compustat and proprietary survey data, he estimates a two step model with the firm's ETR and dummy variables indicating whether the corresponding executives are remunerated based on after-tax measures as endogenous variables. The under taken survey allows him to include not only an indicator variable for the CEO's com-

\footnotetext{
${ }^{9}$ Note that this approach is similar to that of Desai and Dharmapala (2006), even though it yields contrary results. The difference is that Desai and Dharmapala (2006) use the ratio of stock options to total compensation, rather than the ratio of variable compensation (stock options and bonus) to total compensation.
} 
pensation, but also for that of business unit managers within the firm. It was sent to 829 firms, of which 209 yielded usable data, but the author states that (unreported) descriptive statistics suggest that there is no nonresponse bias as measurable with some observable variables. The surveyed firms do, however, significantly differ from the whole sample of Compustat firms in terms of size, capital intensity, leverage, and ETR. Having about two-thirds of CEOs and one third of business unit managers compensated based on after-tax measures, he finds that this leads to a lower ETR in the case of business unit managers, but not for CEOs.

Phillips (2003) does, however, postulate that when the CEO considers the tax department as a profit center, he will hence make sure that the business unit managers also have the proper incentives. Dyreng et al. (2010) also note that CEOs may indirectly influence corporate tax policy by "setting the tone at the top" (p. II64). Gaertner (2013) offers an alternative explanation for the lack of a relationship between CEOs' after-tax incentives and ETRs in Phillips' (2003) study: low statistical power. Gaertner (2013) overcomes this problem by hand-collecting information on whether or not a CEO receives incentives on an after-tax basis from companies' proxy statements. This generates a larger sample than that in Phillips' (2003) study and comes about with higher statistical power. Gaertner's (2013) analysis yields two main results. First, he does indeed find a negative relation between companies' ETRs and the use of after-tax incentives in CEO compensation. Second, he shows that $\mathrm{CEO}$ cash compensation is higher in firms that set after-tax incentives, ceteris paribus. He rationalizes this result with an increased risk for the CEO, for which he demands to be compensated.

\section{Which Firms Avoid Taxes?}

Turning to the question of which firms engage in tax evasion, Dyreng et al. (2008) find that while the average firm in their 1995 to 2004 Compustat sample hardly re- 
duces its tax burden below the statutory tax rate of 35 percent, about a fifth of these firms do so by maintaining an ETR of less than 20 percent. Their exploratory analysis yields I) that these tax-avoiders are concentrated in service industries and in oil and gas extraction and 2) that large firms with incorporation in a tax haven, a high ratio of physical capital, or high leverage tend to have a lower ETR. However, they leave out the question of whether and how CEOs are incentivized to produce these outcomes.

Atwood et al. (1998) analyze a cross section of Compustat data and conduct a text-search of the corresponding proxy statements. They generate a binary variable indicating whether the bonus determinants mentioned in the proxy statements are pre-tax or post-tax measures and aim to explain this variation in the choice of performance indicators with the firms' tax planning opportunities. Firms that employ "earnings", "net income", "return on assets", or "return on equity" as performance measures are considered to give after-tax incentives, with all other cases considered to induce before-tax incentives. Note that firms which use both before- and after tax indicators are dropped from the sample. In their $1993^{-d a t a, ~ r o u g h l y ~ t w o-t h i r d s ~}$ of the 406 firms employ after-tax measures, with the rest using before-tax accounting measures. Their results suggest that bigger, international, more capital intense, more diverse, and less levered firms have more means of manipulating tax obligations and are hence more likely to employ net rather than gross performance measures. The rationale behind the effect of these firm characteristics on tax planning opportunities and thus on the performance measure choice is as follows:

- Size: the bigger a firm is (measured in total sales or total assets), the higher are potential savings from proactive tax planning. As an example, consider a small firm whose total tax burden is so low that incentivizing the CEO to reduce it would be too costly. ${ }^{\mathrm{IO}}$

\footnotetext{
${ }^{\text {Io }}$ This argument requires a non-linear relationship between scale and the costs of tax reduction,
} 
- Multinational Operations: international firms can allocate their incomegenerating processes to jurisdictions with lower corporate taxes.

- Capital Intensity: while a general investment tax credit has been abolished in the U.S. in 1986 , firms that use relatively much capital in their operations have more tax planning opportunities "due to timing issues regarding asset acquisitions, asset dispositions and differences in the tax consequences of buying versus leasing" (Atwood et al. I998, p. 3I) and because they can exploit differences in local and state taxes. ${ }^{I I}$

- Diversity: firms with more operating segments have the opportunity to offset gains in one business unit with losses in another.

- Leverage: using debt instead of equity reduces the tax burden because interest payments generally are a deductible business expense (cf. Internal Revenue Service 2013b). Atwood et al. (I998) argue that a high-levered firm will hardly have any leeway to further reduce tax payments, since the high deductions from interests exhaust the possibilities to lower taxes.

They also include inventory intensity (inventory per total assets) and 5 industry dummies in their regression, out of which only the coefficient for the service industry is significant: service providers seem to be more likely to employ after-tax performance measures.

While these studies give some insight for the design of our empirical analysis, they might be subject to a selection bias. One could for example argue that it is in the interest of the firms which incentivize their CEOs to reduce corporate tax for example a fixed cost.

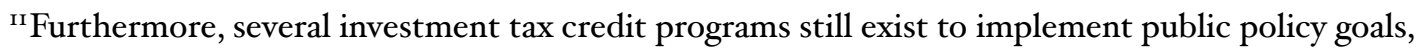
such as renewable energy investment tax credits (cf. Internal Revenue Service 2013). 
payments to avoid that their conduct becomes public knowledge: if the tax authorities know that a firm sets incentives to keep taxes low, they might tend to increase auditing efforts at that particular firm. As a consequence, firms that actively encourage their managers to keep taxes low might be the same ones that give inconclusive information in their proxy statements (cf. Atwood et al. I998 who had to drop 266 of their initial 672 observations), leading to a selective sample.

\section{Data and Empirical Strategy}

We test empirically whether managerial bonus payments are related to corporate income taxes, holding constant net profits. We do so by making use of a merged dataset on executive compensation and firm characteristics. A brief discussion of the dataset is given in Subsection I, and our estimation approach is laid out in Subsection 2 .

\section{I Compustat and ExecuComp Data}

For our analysis we employ a dataset that was compiled from Standard \& Poor's (S\&P's) Compustat and ExecuComp databases. The majority of the firms for which ExecuComp data is available are listed in the S\&P I500 index. While it could be argued that the focus on such a dataset limits the generalizability of our results, we aim to offer an improvement over similar studies that were described in the last section; not only does the S\&P I500 represent some $90 \%$ of the U.S. market capitalization (cf. Standard \& Poor's 20I4), but it also lets us draw inferences concerning smaller firms, since it is comprised of the $\mathrm{S} \& \mathrm{P} 500$ (large-cap firms), the $\mathrm{S} \& \mathrm{P} 400$ (mid-cap firms), and the S\&P 600 (small-cap firms). In accordance with the literature (Phillips 2003, Desai and Dharmapala 2006, Rego and Wilson 2012), we limit 
our analysis to firms with positive pre-tax income. ${ }^{\mathrm{I2}}$ We further drop all firms that are not incorporated in the United States in order to ensure a common institutional framework for all analyzed firms. Finally, we discard observations that have a missing value for any of the variables that we use in the remainder of this paper so that all estimations are undertaken with the same sample. This yields a dataset on 2,830 firms for the years 1992 to 2010 , with some firms not covered in all years, yielding 2I,92I datapoints. The sample attrition is documented in the appendix.

A first overview of the variables used in the analysis is offered in Table I, stating their means and ranges. The dependent variable bonus represents the total annual bonus paid to the CEO and is measured in thousands of dollars. Both explanatory variables are measured in millions of dollars and have been corrected for bonus expenses: income, the firm's net income, and incometax, the corresponding corporate income tax. ${ }^{13}$ All firms have been matched to an industry according to four-digit Standard Industrial Classification (SIC) codes; when these were unavailable an industry has been assigned based on the Compustat variable industry or, if unavailable too, on information from the company website. The dummy variable foreign indicates whether or not a firm generates income abroad. We further generate indicators based on the variables size, the firm's total assets, capitalintensity, the ratio of total property, plant, and equipment to total assets, and leverage, the ratio of debt to total assets.

Table 2 gives the means of our three key variables in subsamples based on different categories. It shows that bigger firms tend to have higher net profits and pay higher bonuses. The average bonus, however, increases relatively less than income, which could be an indication that the sensitivity of the bonus to net income decreases with firm size. Consistent with Murphy (I999), we can see notable differ-

\footnotetext{
${ }^{12}$ Note that we may still observe negative post-tax income.

${ }^{13}$ The procedure for correcting for bonus expenses is documented in the Appendix.
} 
Table I: Means and Ranges of Variables, $\mathrm{n}=2$ I92I

\begin{tabular}{|c|c|c|c|c|}
\hline Variable & Mean & $\mathrm{SD}$ & Min & Max \\
\hline bonus & 900 & I694 & $\mathrm{O}$ & $7695 \mathrm{I}$ \\
\hline income & 372 & $\mathrm{I} 284$ & -1130 & $45^{223}$ \\
\hline incometax & 65 & $3 \mathrm{I} 7$ & -396 & I0655 \\
\hline Agriculture and Mining & 0.012 & $\mathrm{I} .720$ & $\mathrm{o}$ & I \\
\hline Communication & 0.024 & O.I 48 & $\mathrm{O}$ & I \\
\hline Construction & 0.012 & O.IO4 & $\mathrm{O}$ & I \\
\hline Electrics and Electronics & 0.092 & $0.28 \mathrm{I}$ & $\mathrm{O}$ & I \\
\hline Financial Institutions & 0.094 & 0.296 & $\mathrm{O}$ & I \\
\hline Food, Beverages, Tobacco & 0.033 & 0.178 & $\mathrm{O}$ & I \\
\hline Manufacturing & $0.03 \mathrm{I}$ & O.I78 & $\mathrm{O}$ & I \\
\hline Oil and Gas & 0.029 & 0.163 & $\mathrm{O}$ & I \\
\hline Other Industrials & 0.238 & 0.429 & $\mathrm{O}$ & I \\
\hline Other Services & 0.090 & $0.28 \mathrm{I}$ & $\mathrm{O}$ & I \\
\hline Real Estate & O.OOI & 0.030 & O & I \\
\hline Software & 0.056 & 0.237 & $\mathrm{O}$ & I \\
\hline Vehicles & 0.030 & 0.178 & $\mathrm{O}$ & I \\
\hline Transportation & 0.060 & 0.237 & $\mathrm{O}$ & I \\
\hline Utilities & 0.066 & 0.252 & $\mathrm{O}$ & I \\
\hline Wholesale and Retail & $\mathrm{O} . \mathrm{I} 32$ & $0.34 \mathrm{I}$ & $\mathrm{O}$ & I \\
\hline foreign & 0.472 & 0.503 & $\mathrm{O}$ & I \\
\hline size & IOI8I & 53989 & O.I48 & 2187631 \\
\hline capitalintensity & 0.544 & 0.400 & $\mathrm{o}$ & 5.876 \\
\hline leverage & 0.224 & 0.192 & $\mathrm{O}$ & 2.616 \\
\hline
\end{tabular}


Table 2: Conditional Means, $\mathrm{n}=2$ I92I

\begin{tabular}{|c|c|c|c|}
\hline Subsample & bonus & income & incometax \\
\hline Small Firms & $282.8 \mathrm{I}$ & $24 \cdot 37$ & 2.96 \\
\hline Medium-sized Firms & $727 . \mathrm{II}$ & II $4 \cdot 72$ & $\mathbf{1 7 . 7 4}$ \\
\hline Large Firms & I 874.00 & I233.36 & 221.77 \\
\hline Agriculture and Mining & $975 \cdot 34$ & I88.47 & 26.6I \\
\hline Communication & $1803.7 \mathrm{I}$ & 975.65 & 175.25 \\
\hline Construction & $2839 \cdot 34$ & 192.54 & 13.76 \\
\hline Electrics and Electronics & 699.25 & 290.58 & $55 \cdot 73$ \\
\hline Financial Institutions & I712.I6 & 632.62 & 49.69 \\
\hline Food, Beverages, Tobacco & $\mathrm{I} 235 . \mathrm{I} 7$ & $68 \mathrm{I} \cdot 45$ & $97 \cdot 73$ \\
\hline Manufacturing & 629.50 & 317.67 & 19.27 \\
\hline Oil and Gas & IIO2.8O & $348.5 \mathrm{I}$ & $43.8 \mathrm{I}$ \\
\hline Other Industrials & $8 \mathrm{I} 7.5 \mathrm{I}$ & 454.98 & IOI.73 \\
\hline Other Services & 719.96 & II 8.30 & I 7.04 \\
\hline Real Estate & I698.86 & 202.14 & I9.2I \\
\hline Software & $654 \cdot 45$ & 358.84 & $\mathrm{IO} 2.3 \mathrm{I}$ \\
\hline Vehicles & III 7.69 & 5II.IO & 91.15 \\
\hline Transportation & 598.66 & $\mathrm{I} 47.83$ & 37.10 \\
\hline Utilities & 526.39 & $284 \cdot 37$ & 76.15 \\
\hline Wholesale and Retail & 718.37 & 247.14 & 29.59 \\
\hline No Foreign Income & 783.36 & $25 \mathrm{I} .20$ & $37 \cdot 35$ \\
\hline Foreign Income & IO36.44 & 506.82 & 96.07 \\
\hline Low Leverage & 822.47 & 349.01 & 63.38 \\
\hline High Leverage & 982.34 & $394 \cdot 36$ & $66.7 \mathrm{I}$ \\
\hline Low Capitalintensity & IOO5.I8 & $372.5 \mathrm{I}$ & 56.50 \\
\hline High Capitalintensity & 806.83 & 371.09 & 73.04 \\
\hline
\end{tabular}


ences between industries in terms of bonus, income, and incometax. The average firm in the Oil and Gas industry, for example, pays its CEO a bonus almost twice the size than its counterpart in the Software industry, while their net income is comparable. Interestingly, they also pay much lower taxes. Firms that generate income abroad have almost double the net income of domestic-only firms, while paying a higher bonus and relatively more taxes. ${ }^{I 4}$ Highly-levered firms pay relatively less taxes in comparison with lowly-levered firms, while paying a higher bonus. With their net income almost exactly the same, firms with a low capital intensity also pay a higher bonus and less taxes than companies with a high capital intensity. ${ }^{15}$

Note that these are univariate comparisons and that the differences in averages could also be driven by level effects. It may be that larger firms pay a relatively lower bonus because they can incentivize their CEOs more easily, either because the prospect of a certain absolute amount of bonus payments suffices, or because equity incentives are provided. It may just as well be the case that the relatively low bonus can be explained as a punishment for relatively high tax payments. Likewise, unobserved heterogeneity within an industry, or even within a firm, may necessitate a certain level of bonus payments. A regression framework with fixed firm effects allows us to relate variations in the bonus to variations in firm income and income taxes, rather than only comparing the levels of averages.

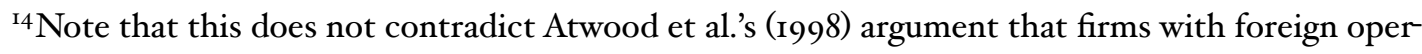
ations have higher tax saving opportunities. An unobserved characteristic may cause these firms to have a high tax burden, while still having many opportunities for tax savings.

${ }^{15}$ Idem. High capital intensity may come about with higher average income taxes and thereby give more leeway to manipulate taxes.
} 


\subsection{Econometric Framework}

Each firm in our dataset has its own executive compensation plan and ideally one would be able to make inferences about each individual bonus plan. Unfortunately, we have less than eight observations per firm on average, not allowing us to do this. ${ }^{16}$ We thus resort to estimating a model that lets us make statements about the average bonus contract and later refine our analysis by focussing on several subsamples. Our baseline specification controls for time-invariant firm effects and firm-invariant time effects:

$$
\text { bonus }_{i t}=\beta_{1} \text { income }_{i t}+\beta_{2} \text { incometax }_{i t}+\lambda_{i}+\lambda_{t}+\varepsilon_{i t},
$$

where bonus $_{i t}$ denotes the realization of the bonus paid to the CEO by firm $i$ in year $t$, income $i t$ the firm's net income before extraordinary expenses in that year, and incometax $_{i t}$ the corresponding tax.

The company fixed effects account for unobserved heterogeneity that influences the level of bonuses in a particular firm. Macroeconomic and other factors that might affect the bonus in all firms in a given year are controlled for by the time effects.

We can now easily test the following hypothesis:

Ho:

$$
\beta_{2}=0
$$

holding net income constant, the bonus does not depend on corporate income taxes.

\footnotetext{
${ }^{16}$ Note that in one of his robustness checks, Gaertner (2013) generates a variable indicating whether a firm uses after-tax incentives with this very technique. Due to the low number of observations, however, he needs to resort to an uncommon threshold of significance.
} 
The coefficient $\beta_{2}$ tells us the impact of the firm's income tax payments on the CEO's bonus, holding constant firm income. If firm profits are taxed linearly, the regression framework would not allow us to deduce statements on this effect, since both explanatory variables would be perfectly collinear. Now, if we do find $\beta_{2}$ to be significantly different from zero, this is only caused by variations in incometax that arise independently of those in income. As an example, consider a firm who pays a bonus based only on net income. Now further assume that gross profits increase simultaneously with a raise in the tax rate such that net profits remain exactly the same. As a consequence, the CEO bonus remains unchanged while there was a change in incometax, yielding a coefficient estimate of $\beta_{2}=0$. If this weren't the case, we could deduce that the bonus must be tied to other measures than just net income, for example to gross income, to another measure that correlates with it, or even explicitly to tax payments themselves.

We can conceive the following combinations of coefficient estimates:

- $\beta_{1}=0 ; \beta_{2}=0$ : we cannot show that CEO bonus payments are associated with either corporate net income or corporate tax payments.

- $\beta_{1}>0 ; \beta_{2}=0$ : while firms do incentivize their CEOs to increase net income, we cannot reject the null hypothesis that the CEO bonus is independent of corporate tax payments.

- $\beta_{1}>0 ; \beta_{2}>0 ; \beta_{1} \geq \beta_{2}$ : firms set incentives related to a mixture of pre-tax and post-tax corporate income.

- $\beta_{1}>0 ; \beta_{2}<0$ : in addition to rewarding increases in net rather than in gross income, the firm sets further incentives to reduce corporate tax payments.

Our conjecture based on previous studies would be that we find a coefficient on incometax that is lower than that of income. Note that this would be an average 
result and would not mean it applies to all firms. While it might be possible that some firms mix pre- and post-tax incentives in their bonus contracts, we expect firms to use either one, possibly in combination with other incentives to reduce taxes. We will explore whether there are any regularities concerning the coefficient estimates conditional on observable firm characteristics with the following specification:

bonus $_{i t}=\sum_{j} \beta_{1 j} *$ subsample $_{j} *$ income $_{i t}+\sum_{j} \beta_{2 j} *$ subsample $_{j} *$ incometax $_{i t}+\lambda_{i}+\lambda_{t}+\varepsilon_{i t}$.

We divide the sample into subsamples based on industry and size. For the sake of easier interpretation in a multivariate comparison of the coefficients of income and incometax, we reformulate Equation 3 to:

$$
\begin{gathered}
\text { bonus }_{i t}=\beta_{11} * \text { income }_{i t}+\beta_{21} * \text { incometax }_{i t}+\sum_{j \neq 1} \beta_{1 j} * \text { subsample }_{j} * \text { income }_{i}(4) \\
+\sum_{j \neq 1} \beta_{2 j} * \text { subsample }_{j} * \text { incometax }_{i t}+\lambda_{i}+\lambda_{t}+\varepsilon_{i t},
\end{gathered}
$$

where the subsamples are generated based on tax planning opportunities in terms of foreign operations, leverage, size, and capital intensity. The reference subsamples are denoted by $j=1$.

\section{Results}

This section exhibits the results obtained from regressing CEO bonus payments on the corresponding firms' net income and corporate income tax. The first subsection presents the results of the baseline specification and its extensions, followed by a discussion of possible limitations in Subsection 2.

\section{I Baseline Specification and Extensions}

In this subsection, we present the results from estimating Equations I, 3, and 4. The baseline regression yields the following results (Table 3): 


\begin{tabular}{|c|c|}
\hline Explanatory Variable & Coefficient \\
\hline income & $\begin{array}{c}0.338^{* * *} \\
(0.013)\end{array}$ \\
\hline incometax & $\begin{array}{c}-0.258^{* * *} \\
(0.052)\end{array}$ \\
\hline Firm and Year effects & Yes \\
\hline Number of Firms & 2830 \\
\hline
\end{tabular}

Notes: the dependent variable is the bonus paid to the CEO. income is the firm's net income corrected for bonus expenses. incometax is the corresponding payable income tax, also corrected for bonus expenses. The specification includes time-invariant firm effects and firm-invariant time effects. The sample period is 1992 to 2010 . Standard errors are in parentheses and significance at the $1 \%, 5 \%$, and I0\% levels is indicated by ${ }^{* * *},{ }^{* *}$, and ${ }^{*}$, respectively.

The results displayed in Table 3 imply that a one million dollar increase in a firm's net income is associated with an increase in the CEO's bonus of 338 dollars. ${ }^{17}$ They further allow us to reject the hypothesis that tax payments do not play a role in any CEO's bonus contract: holding net income constant, a reduction of payable taxes by one million dollars comes about with a 258 dollar increase in the executive's bonus. This is a noteworthy result since it implies that shareholders reward an income increase that comes from tax savings more strongly than other net income increases. A possible explanation is that CEOs require to be compensated for the additional risk borne in tax saving activities (cf. Chen and Chu 2005, and Rego and Wilson 20I2). Bonus contracts that are based on more than one performance measure are often designed in an additive fashion so that they can be thought of as a sum of separate bonus plans (cf. Murphy 1999). Our coefficient estimates could be the result of such an additive bonus plan. Firms might, for example, base part of the bonus on net income and explicitly reward a reduction of corporate taxes in another part

\footnotetext{
${ }^{17}$ Our estimate for the sensitivity of the bonus to firm income is considerably smaller than the estimates for the sensitivity of CEO wealth to shareholder wealth which were mentioned in the Introduction. Note that the bonus only accounts for a part of annual compensation and that it is a flow variable, whereas $\mathrm{CEO}$ wealth is a stock variable, comprising all previous stock and option grants among other elements. Furthermore, the value of these equity incentives is tied per definition to the stock yield, and thus to shareholder wealth, whereas the bonus can depend on various measures.
} 
of the bonus. ${ }^{18}$ Whatever the case may be, this is still an average result and the literature presented above suggests that firms' compensation practices differ across a number of variables.

Table 4: Subsamples: Firm Size, n=2192I

\begin{tabular}{ccc}
\hline \hline Subsample & income & incometax \\
\hline Small Firms & $3.24 \mathrm{I}^{* * *}$ & $\mathrm{I} .98 \mathrm{O}$ \\
& $(0.8 \mathrm{I} 6)$ & $(3.725)$ \\
Medium-sized Firms & $0.978^{* * *}$ & -0.407 \\
& $(0.113)$ & $(0.705)$ \\
Large Firms & $0.337^{* * *}$ & $-0.25 \mathrm{I}^{* * *}$ \\
& $(0.013)$ & $(0.052)$
\end{tabular}

Notes: the dependent variable is the bonus paid to the CEO. income is the firm's net income corrected for bonus expenses. incometax is the corresponding payable income tax, also corrected for bonus expenses. The specification includes time-invariant firm effects and firm-invariant time effects. Medium-sized firms are the $50 \%$ of firms around the median firm in terms of size measured by total assets. Small firms and large firms are the smallest and largest $25 \%$ of firms in terms of total assets, respectively. The sample period is 1992 to 2010 . Standard errors are in parentheses and significance at the $\mathrm{I} \%, 5 \%$, and I0\% levels is indicated by ${ }^{* * *},{ }^{* *}$, and ${ }^{*}$, respectively.

Following Equation 3, we estimate the coefficients for income and incometax separately for subsamples based on firm size and industry. Table 4 depicts the results for the subsamples based on firm size and lets us draw two conclusions: I) The larger a firm is, the lower is the sensitivity of the bonus to the firm's net income. While a one million dollar increase in net income leads to a bonus increase of $324 \mathrm{I}$ dollars for small firms, the same increase in net income only leads to a bonus increase of 337 dollars for a large firms. 2) Holding net income constant, we cannot reject the hypothesis that tax payments do not affect the bonus in small and medium-sized firms - it seems that CEOs in these companies are simply compensated based on net profits and taxes do not play a role. Apparently, our results from the baseline specification are driven by large firms, in which a one million dollar increase is associated with a $25 \mathrm{I}$ dollar bonus increase.

\footnotetext{
${ }^{18}$ Ittner et al. (1997) find that some $8 \%$ of bonus plans reward "cost reduction", which may comprise tax expenses.
} 
We now repeat the analysis for different industries (Table 5). As was put forward by Murphy (I999), there is quite some heterogeneity between the coefficient estimates for the different industries. The results can be grouped into four categories:

- Positive income, insignificant incometax coefficients: ${ }^{19}$ While a higher net income is accompanied by a higher bonus, we cannot reject our null hypothesis, that is, we have no reason to believe tax payments have an impact on the CEO's bonus - over and above their direct effect on net income - for firms in the Agriculture and Mining, Communication, Food, Beverages and Tobacco, Oil and Gas, Real Estate, Vehicles, Utilities, and Other Service industries.

- Positive income, positive incometax coefficients: Firms in three industries pay their CEOs a higher bonus when incometax is high, holding constant income. One explanation could be that the bonus remuneration is based on gross-, rather than net-income, at least for Financial Institutions. For the Construction and Transportation industries, however, the incometax coefficient estimate is surprisingly high. One rationale behind this could be that CEOs are in fact incentivized to generate high tax payments. This scenario could be relevant if a company is (partly) under public ownership, like many public transportation firms, or otherwise has an interest in high tax payments. It could be argued that construction firms are exposed to a relatively high amount of regulation, bureaucracy, and also business from public infrastructure projects so that they might find it particularly opportune to propitiate the authorities with tax payments. ${ }^{20}$

- Insignificant income, insignificant incometax coefficients: For firms in the Manufacturing and Software industries we find no significant relationship be-

\footnotetext{
${ }^{19}$ We use the term "insignificant" when a coefficient is not significant at the ro\% level.

${ }^{20} \mathrm{~A}$ report of Transparency International (2008) finds that the Construction industry is the one most prone to bribery of public officials. In a similar fashion, firms in this industry might also tend to "bribe" the authorities with high tax payments.
} 
tween the CEO's bonus and either firm income or income taxes. This might be due to the notion that managers' interests in these sectors are only aligned with those of the shareholders by means of equity incentives. ${ }^{21}$

- Positive income, negative incometax coefficients: The results for firms in Wholesale and Retail, Other Industrials, and Electrics and Electronics suggest that on top of being remunerated on net- rather than gross income, CEOs are incentivized to consider taxes as a profit center and to reduce corporate tax payments. Especially for firms in the latter two industries, this seems plausible, since these companies often have tax saving opportunities, such as production facilities abroad.

Following the interpretation of the results of the last category, we estimate Equation 4 incorporating indicators for the firms' tax saving opportunities. The coefficient estimates are shown in Table 6. The results in the first column are particularly interesting. The sensitivity of the bonus to income is not significantly different for firms that have foreign operations and for those that do not. This could be seen as an indication that the general CEO remuneration practices do not differ between firms that only operate domestically and firms that also generate income abroad. They do, however, differ vastly in the sensitivity of the bonus to incometax: after a tax reduction of one million dollars, CEOs in firms with foreign operations receive a bonus 629 dollars higher than a CEO in a domestic firm would receive. This can be interpreted as an indication that internationally active firms have more tax saving opportunities than their domestic-only counterparts. As a consequence, they reward tax savings more strongly. For CEOs in highly-levered firms (Column 2), the

\footnotetext{
${ }^{21}$ Consider for example Google's former CEO and owner of a substantial amount of company stock, Eric Schmidt, who receives a one-dollar salary and declines to benefit from a bonus plan (cf. United States Securities and Exchange Comission 20II). However, in 2009, he still received a holiday bonus of 1660 dollars. Clearly, this amount is independent of firm income or incometax and can vary over time.
} 
Table 5: Subsamples: Industries, $\mathrm{n}=2192 \mathrm{I}$

\begin{tabular}{|c|c|c|}
\hline Subsample & income & incometax \\
\hline Agriculture and Mining & $\begin{array}{l}0.886^{* *} \\
(0.343)\end{array}$ & $\begin{array}{l}-0.091 \\
(2.058)\end{array}$ \\
\hline Communication & $\begin{array}{c}0.473^{* * *} \\
(0.058)\end{array}$ & $\begin{array}{l}-0.102 \\
\text { (0.I80) }\end{array}$ \\
\hline Construction & $\begin{array}{c}9.970^{* * *} \\
(0.399)\end{array}$ & $\begin{array}{c}\mathrm{I} 7.4 \mathrm{II}{ }^{* * *} \\
(2.379)\end{array}$ \\
\hline Electrics and Electronics & $\begin{array}{c}0.756^{* * *} \\
(0.056)\end{array}$ & $\begin{array}{c}-2.154^{* * *} \\
(0.275)\end{array}$ \\
\hline Financial Institutions & $\begin{array}{c}0.597^{* * *} \\
(0.028)\end{array}$ & $\begin{array}{c}0.362^{* * *} \\
(0.108)\end{array}$ \\
\hline Food, Beverages, Tobacco & $\begin{array}{l}0.729^{* * *} \\
(0.076)\end{array}$ & $\begin{array}{l}-0.58 \mathrm{I} \\
(0.395)\end{array}$ \\
\hline Manufacturing & $\begin{array}{c}0.033 \\
(0.053)\end{array}$ & $\begin{array}{c}0.347 \\
(\mathrm{I} .678)\end{array}$ \\
\hline Oil and Gas & $\begin{array}{c}0.782^{* * *} \\
(0.097)\end{array}$ & $\begin{array}{c}0.928 \\
(0.87 \mathrm{I})\end{array}$ \\
\hline Other Industrials & $\begin{array}{l}0.155^{* * *} \\
(0.019)\end{array}$ & $\begin{array}{l}-0.16 \mathrm{I}^{* *} \\
(0.073)\end{array}$ \\
\hline Other Services & $\begin{array}{c}\text { I. } 327^{* * *} \\
(0.234)\end{array}$ & $\begin{array}{c}0.937 \\
(0.899)\end{array}$ \\
\hline Real Estate & $\begin{array}{c}\text { II. } 504^{* *} \\
(5.227)\end{array}$ & $\begin{array}{c}27.947 \\
(23.748)\end{array}$ \\
\hline Software & $\begin{array}{c}0.080 \\
(0.05 \mathrm{I})\end{array}$ & $\begin{array}{c}0.054 \\
(0.192)\end{array}$ \\
\hline Transportation & $\begin{array}{l}0.387^{* *} \\
(0.182)\end{array}$ & $\begin{array}{l}0.902^{*} \\
(0.5 \mathrm{I} 2)\end{array}$ \\
\hline Vehicles & $\begin{array}{c}0.698^{* * *} \\
(0.057)\end{array}$ & $\begin{array}{c}-0.185 \\
(0.269)\end{array}$ \\
\hline Utilities & $\begin{array}{c}0.492^{* * *} \\
(0.139)\end{array}$ & $\begin{array}{c}0.335 \\
(0.43 \mathrm{I})\end{array}$ \\
\hline Wholesale and Retail & $\begin{array}{l}0.685^{* * *} \\
(0.060)\end{array}$ & $\begin{array}{c}-\mathrm{I} . \mathrm{I} 5 \mathrm{O}^{* * *} \\
(0.397)\end{array}$ \\
\hline
\end{tabular}

Notes: the dependent variable is the bonus paid to the CEO. income is the firm's net income corrected for bonus expenses. incometax is the corresponding payable income tax, also corrected for bonus expenses. The specification includes time-invariant firm effects and firm-invariant time effects. All firms have been matched to an industry based on SIC codes; when these were unavailable an industry has been assigned based on the Compustat variable industry or on the company name. The sample period is 1992 to 2010 . Standard errors are in parentheses and significance at the $1 \%, 5 \%$, and $10 \%$ levels is indicated by ${ }^{* * *},{ }^{* *}$, and ${ }^{*}$, respectively. 
Table 6: Tax Sheltering Opportunities, $\mathrm{n}=2$ 2192I

\begin{tabular}{|c|c|c|c|c|}
\hline Variable & (I) & $(2)$ & (3) & $(4)$ \\
\hline income & $\begin{array}{l}0.348^{* * *} \\
(0.026)\end{array}$ & $\begin{array}{l}0.335^{* * *} \\
(0.019)\end{array}$ & $\begin{array}{c}0.447^{* * *} \\
(0.018)\end{array}$ & $\begin{array}{l}\text { I.II } 8^{* * *} \\
(0.130)\end{array}$ \\
\hline income*foreign & $\begin{array}{c}0.006 \\
(0.027)\end{array}$ & & & $\begin{array}{l}0.056^{* *} \\
(0.028)\end{array}$ \\
\hline income*highleverage & & $\begin{array}{l}0.059^{* *} \\
(0.024)\end{array}$ & & $\begin{array}{c}0.028 \\
(0.024)\end{array}$ \\
\hline income*highcapitalintensity & & & $\begin{array}{c}-0.166^{* * *} \\
(0.025)\end{array}$ & $\begin{array}{c}-0.138^{* * *} \\
(0.026)\end{array}$ \\
\hline income*small & & & & $\begin{array}{l}2.226^{* * *} \\
(0.800)\end{array}$ \\
\hline income*large & & & & $\begin{array}{c}-0.717^{* * *} \\
(0.126)\end{array}$ \\
\hline incometax & $\begin{array}{c}0.319^{* * *} \\
(0.112)\end{array}$ & $\begin{array}{c}-0.454^{* * *} \\
(0.075)\end{array}$ & $\begin{array}{l}-0.062 \\
(0.062)\end{array}$ & $\begin{array}{c}0.334 \\
(0.523)\end{array}$ \\
\hline incometax*foreign & $\begin{array}{c}-0.629^{* * *} \\
(0.114)\end{array}$ & & & $\begin{array}{c}-0.629^{* * *} \\
(0.117)\end{array}$ \\
\hline incometax*highleverage & & $\begin{array}{l}0.474^{* * *} \\
(0.096)\end{array}$ & & $\begin{array}{c}0.310^{* * * *} \\
(0.097)\end{array}$ \\
\hline incometax*highcapitalintensity & & & $\begin{array}{c}-0.335^{* * *} \\
(0.098)\end{array}$ & $\begin{array}{c}-0.375^{* * *} \\
(0.102)\end{array}$ \\
\hline incometax*small & & & & $\begin{array}{c}2.310 \\
(3.697)\end{array}$ \\
\hline incometax*large & & & & $\begin{array}{c}0.039 \\
(0.510)\end{array}$ \\
\hline
\end{tabular}

Notes: the dependent variable is the bonus paid to the CEO. income is the firm's net income corrected for bonus expenses. incometax is the corresponding payable income tax, also corrected for bonus expenses. The specification includes time-invariant firm effects and firm-invariant time effects. For the univariate results based on size-subsamples, see Table 4 . The indicator variables are equal to one if: foreign - the firm has nonzero foreign income (Io340 firms), highleverage - the firm's leverage is above the median value, highcapitalintensity - the firm's capital intensity is above the median value, small - the firm belongs to the smallest $25 \%$ of firms in terms of total assets, large - the firm belongs to the largest $25 \%$ of firms in terms of total assets. The sample period is 1992 to 2010 . Standard errors are in parentheses and significance at the $1 \%, 5 \%$, and Io\% levels is indicated by ${ }^{* * *},{ }^{* *}$, and ${ }^{*}$, respectively. 
negative coefficient for incometax is almost exactly offset by the interaction term. Apparently the reasoning laid out in Atwood et al. (1998) seems to apply: firms that are financed with relatively more debt already save taxes by declaring interest payments as a business expense, limiting their possibilities to further reduce incometax. Thus, CEOs in those firms are not specifically incentivized to do so. Also in accordance with their findings, capital-intense firms highly encourage tax reductions in comparison with less capital-intense firms (Column 3).

Note that this is a univariate comparison of the coefficients for income and incometax. In order to alleviate this concern, we estimate the model with all tax saving indicators, in addition to firm size, at once (Column 4). The coefficients for the different interaction terms now give the slope effect of tax saving opportunities compared to the reference group of mid-sized companies with only domestic operations, low leverage, and low capital intensity. The effects of tax planning opportunities on the sensitivity of the bonus to corporate income taxes remain qualitatively unchanged. Nonetheless, the interaction terms of incometax and size are insignificant. The interpretation of this result is that, in comparison to mid-sized, domestic-only, low-levered companies with low capital intensity, company size does not have a significant effect on the sensitivity of the bonus to income tax.

\subsection{Discussion}

After finding out which CEOs are given incentives to reduce corporate taxes, the obvious next step would be to find out whether these incentives work and such executives actually do reduce tax payments. Using different firm-level proxies for taxreduction incentives, studies like Phillips (2003), Armstrong et al. (2012), or Gaertner (2OI3) find evidence on this, which could give rise to concerns about reverse causality. However, our study presents results of the relationship between intra-firm variations in taxes and variations of bonus payments, while the mentioned studies 
find an effect of variations in this very relationship on variations of a function of tax payments. One is generally confronted with a problem of reverse causality when one wants to estimate the effect of B on A, but in reality, A (also) causes variations in B. In our context, this could be the case when, for example, an increase in the sensitivity of the bonus to the firm's tax payments leads him to reduce corporate taxes, which is not just a possibility, but a conjecture that motivates our study. Nonetheless, this concern does not pose a problem for our study since the bonus contract specifies ex ante how variations in tax payments will impact the manager's bonus. The CEO observes this contract and undertakes the actions that maximize his utility. This will yield a realization of tax payments, according to which his bonus is calculated and paid out. We are interested in the contracted relationship between taxes and bonus and our data allow us to estimate this relationship, regardless of whether or not it induces the CEO to undertake actions aimed at reducing tax payments.

It could be argued that we are prone to spurious results because of omitted variables that may affect CEO bonuses. In principle, it is conceivable that such left-out variables are correlated with both, income and tax. As an example, imagine a CEO's bonus is tied to the total revenue and to the return on assets of his firm. While neither income nor tax are explicitly mentioned in his bonus contract, our estimation setup could yield significant coefficients for both measures. This is so because total revenue determines both measures and return on assets is a function of net income. This is, however, acceptable for our analysis, since this mechanism entails that the $\mathrm{CEO}$ is in fact incentivized implicitly to manipulate net income and taxes.

Finally, it must be noted that when we cannot reject the hypothesis that the coefficient on incometax is equal to zero, this does not have to be the case because taxes do in fact not play a role in the CEO's bonus plan; it is possible that this 
occurs due to a lack of variations in incometax that are independent of variations in income. However, in most cases we do find significant coefficients on incometax, which allows us to dismiss this concern. If anything, it supports the view that we give a lower bound of the statistical significance of our coefficient estimates.

\section{Concluding Remarks}

The aim of this paper was to test whether CEOs' bonus contracts set incentives to reduce corporate tax payments. Our study shows this is indeed the case when looking at the whole sample, where we find that bonuses increase with tax reductions, while controlling for net income. In some instances, however, the contrary is the case; CEOs in the Construction and Transportation industries even seem to be incentivized to generate high tax payments. It appears that the result of the estimation over the whole sample is driven by firms in the Wholesale and Retail, Electrics and Electronics, and Other Industrial sectors, which account for almost half of the sample. In accordance with previous literature, we further find that a number of proxies for tax planning opportunities are related to a high negative sensitivity of the bonus to income tax payments.

These results provide a lower-bound estimate of the CEO's incentives to reduce corporate taxes, since equity compensation that is paid in addition to the bonus automatically sets such incentives. Keeping this in mind, our results are particularly noteworthy, since they imply that a profit increase from tax savings is rewarded more strongly than profit increases from other sources. A possible explanation could be that running an aggressive tax strategy is not only costly to the CEO in terms of effort, but it could also bear additional risk for him. This hypothesis is in line with Gaertner (2OI3). Apart from a potentially higher volatility of firm fundamentals, and thus of the bonus payments, the executive might incur personal risks such as a loss 
of reputation (cf. Rego and Wilson 20I2), or even the threat of legal prosecution. Federal law (cf. Office of the Law Revision Counsel 2010) subjects all responsible persons who willfully retain due taxes from the government to a penalty equal to the taxes withheld. A decision of the United States District Court Middle District of Florida Tampa Division (2009) shows that a CEO can indeed be considered a "responsible person" and can be held personally liable for withholding taxes from the government.

From a shareholders' perspective, setting such incentives makes sense if the expected gains from running an aggressive tax strategy exceed the expected costs from potential risk to firm value and from incentivizing the CEO. Graetz (2008) postulates that "a tax shelter is a deal done by very smart people that, absent tax considerations, would be very stupid" (p. II6). From an economist's perspective, the conduct of incentivizing a CEO to act in such a "very stupid" way can be seen as an instance of rent seeking; it is a costly activity that leads to a redistribution, rather than the production, of wealth. 


\section{References}

Allingham, G. and A. Sandmo (I972): "Income Tax Evasion: a Theoretical Analysis", Journal of Public Economics, I, 323-338.

Armstrong, C. S., J. L. Blouin, and D. F. Larcker (2OI2): “The Incentives for Tax

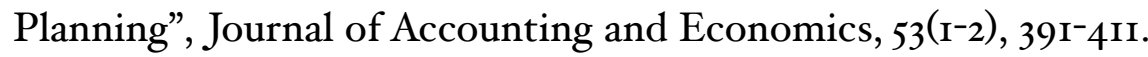

Atwood,T. J., T. Omer, and M. Shelley (I998): "Before-Tax Versus After-Tax Earnings As Performance Measures In Compensation Contracts”, Managerial Finance, $24(\mathrm{II}), 29^{-} 44$.

Becker, G. (I968): “Crime and Punishment: An Economic Approach”, Journal of Political Economy, 76, I69-217.

Chen, K. P. and C. Y. C. Chu (2005): "Internal Control vs. External Manipulation: A Model of Corporate Income Tax Evasion”, Rand Journal of Economics, 36(I), I5I-I64.

Crocker K.J. and J. Slemrod (2005): "Corporate tax evasion with agency costs", Journal of Public Economics, 89(9-10), 1593-1610.

Desai, M. A. and D. Dharmapala (2006): “Corporate Tax Avoidance and HighPowered Incentives", Journal of Financial Economics, 79(I), I45-I79.

Dyreng, S., M. Hanlon, and E. L. Maydew (2008): "Long-Run Corporate Tax Avoidance", The Accounting Review, 83(I), 6I-82.

Dyreng, S., M. Hanlon, and E. L. Maydew (2OIO): "The Effects of Executives on Corporate Tax Avoidance", The Accounting Review, 85(4), II63-II89. 
Frydman, C. and D. Jenter (2010): “CEO Compensation”, Working Paper, Rock Center for Corporate Governance at Stanford University.

Gaertner, F. B. (2013): “CEO After-Tax Compensation Incentives and Corporate Tax Avoidance", Contemporary Accounting Research, Forthcoming.

Graetz, M. (2008): “ıоo Million Unnecessary Returns: A Simple, Fair, and Competitive Tax Plan for the United States”, New Haven, CT: Yale University Press.

Hall, B. and J. Liebman (I998): “Are CEOs really paid like bureaucrats?”, Quarterly Journal of Economics, II3(3), 653-691.

Internal Revenue Service (2013): "Energy Incentives for Businesses in the American Recovery and Reinvestment Act”, URL http://www.irs.gov/uac/Energy-Incentives-for-Businesses-in-the-American-Recoveryand-Reinvestment-Act, retrieved on $2014^{-0} 3^{-}-13$.

Internal Revenue Service (2013b): "Publication 535, Business Expenses”, URL http://www.irs.gov/publications/p535/cho4.html\#doe2I29, retrieved on 2014-03-13.

Ittner, C. D., D. F. Larcker, and M. V. Rajan (I997): "The Choice of Performance Measures in Annual Bonus Contracts", The Accounting Review, 72(2), $23 \mathrm{I}^{-255}$.

Jensen, M. C. and K.J. Murphy (I990): "Performance Pay and Top Management Incentives", Journal of Political Economy, 98(2), 225-264.

Murphy, K. J. (I999): "Executive compensation”, in Orley, A., David, C. (Eds.), Handbook of Labor Economics, 3, Amsterdam.

Murphy, K. J. (2000): "Performance Standards in Incentive Contracts”, Journal of Accounting and Economics, 30(3), 245-278. 
Office of the Law Revision Counsel (2010): " $\$$ 6672. Failure to collect and pay over tax, or attempt to evade or defeat tax", U.S. House of Representatives, URL http://uscode.house.gov/uscode-cgi/fastweb.exe?getdoc+uscview+t26t28+2I $93+1++\% 28$ \%29\%20\%2OAND\%20\%28USC\%2Ow\%2FIO\%2O\%286672\%29\%29\%3ACITE\%2O $\% 20 \% 20 \% 20 \% 20 \% 20 \% 20 \% 20 \% 20$, retrieved on $2013^{-0} 3^{-0} 4$.

Phillips, J. (2003): "Corporate tax planning effectiveness: The role of compensationbased incentives", The Accounting Review, 78(3), 847-874.

Rego, S. and R. Wilson (20I2): "Equity Risk Incentives, and Corporate Tax Aggressiveness", Journal of Accounting Research, 50(3), 775-810.

Slemrod, J. (2007): "Cheating Ourselves: The Economics of Tax Evasion”, Journal of Economic Perspectives, 2I(I), 25-48.

Standard \& Poor's (2014): "S\&P Composite 1500® - S\&P Dow Jones Indices", URL http://www.spindices.com/indices/equity/sp-composite-1500, retrieved on 20I4$\mathrm{O}^{-} \mathrm{I} 3$.

Transparency International (2008): "Bribe Payers Index", URL http://www.transparency.org/ content/download/39275/622457, retrieved on $2013^{-02-26}$.

United States District Court Middle District of Florida Tampa Division (2009): “Doulgeris v. United States of America”, URL

http://docs.justia.com/cases/federal/district-courts/florida/flmdce/8:2008cvoo282/210I69/67/, retrieved on $2013^{-}-3^{-}-04$.

United States Securities and Exchange Comission (20II): "Definitive Proxy Statement”, URL http://www.sec.gov/Archives/edgar/data/I288776/000II93I25IO070028/ddefI4a.htm, retrieved on $2013^{-02-26 . ~}$ 


\section{Appendix}

\section{Sample Attrition}

The total number of observations is reached as follows.

\begin{tabular}{cc}
\multicolumn{2}{c}{ Table 7: Sample Attrition } \\
\hline Observations with... & Number of Observations \\
\hline Match in Compustat and Execucomp & 29379 \\
Missing values for any variable & -2205 \\
Negative pre-tax income & -4824 \\
Foreign incorporation & -428 \\
Negative bonus & - I \\
Total & 2I92I
\end{tabular}

\section{Correction for compensation expenses}

Since it would be counterintuitive if a company rewarded the CEO for tax savings due to expenses for his own bonus (cf. Chen and Chu 2005), we correct our two main explanatory variables income and incometax for bonus expense. Consider the following simple model of linear profit taxation:

$$
\pi^{\text {gross }}=\pi^{\text {net }}+T=(1-\tau) \pi^{\text {gross }}+\tau * \pi^{\text {gross }}=R-C_{1}-C_{2},
$$

where $\pi$ denotes profits, $\tau$ the tax rate and $T, R, C_{1}, C_{2}$ are payable income taxes, revenue, business expenses, and CEO bonus expenses, respectively. We observe $\pi^{\text {net }}, T$, and $C_{2}$ and want to construct a measure of net profits before bonus expense, $\hat{\pi}^{n e t}$, and a measure of income taxes before bonus expense, $\hat{T}$. Since

$$
\pi^{\text {gross }}=\pi^{\text {net }}+T=(1-\tau)\left(R-C_{1}-C_{2}\right)+\tau\left(R-C_{1}-C_{2}\right),
$$


we get that

$$
\hat{\pi}^{n e t}=(1-\tau)\left(R-C_{1}\right)=(1-\tau)\left(R-C_{1}-C_{2}\right)+(1-\tau) C_{2}=\pi^{n e t}+(1-\tau) C_{2}, \quad(7)
$$

and likewise

$$
\hat{T}=\tau\left(R-C_{1}\right)=\tau\left(R-C_{1}-C_{2}\right)+\tau C_{2}=T+\tau C_{2}
$$

Using that $\tau=\frac{T}{\pi^{n e t}+T}$, these variables can readily be constructed with the variables in our dataset.

\section{Variable Definitions}

The variables we use have the following relationship to Compustat / ExecuComp items.

Table 8: Variable Definitions

\begin{tabular}{cc}
\hline \hline Variable & Compustat/ExecuComp Item \\
\hline bonus & $B O N U S+N O N E Q \_I N C E N T$ \\
income & $I B+\left(1-\frac{T X P}{I B+T X P}\right)\left(B O N U S+N O N E Q \_I N C E N T\right)$ \\
size & $T X P+\frac{T X P}{I B+T X P}\left(B O N U S+N O N E Q \_I N C E N T\right)$ \\
foreign & $A T$ \\
leverage & 1 if $P I F O \neq 0$ \\
capitalintensity & $\frac{D L T T+D L C}{A T}$ \\
\end{tabular}

\section{Notes}

The expressions "income" and "profits" are used interchangeably. Unless otherwise noted, they refer to the after-tax measure. 
Similarly, expressions such as "tax avoidance", "tax sheltering", or "tax evasion" are used synonymously and are not supposed to indicate whether the activity is legal or not, unless otherwise noted.

The variable bonus is measured in thousands of dollars; all other dollar-measures are given in millions of dollars.

Dates are expressed in compliance with ISO 860I. 